\title{
Speeding Intention among Young Urban Drivers
}

\author{
Dayang Norfazila Abang Mustaffaa, Mohamad Ghazali Masuria*, \\ Akehsan Dahlanª Khairil Anuar Md. Isab \\ aOccupational Therapy Department, bBasic Sciences Department, \\ Faculty of Health Sciences, UiTM Kampus Puncak Alam, Selangor \\ zalie222@gmail.com
}

\begin{abstract}
The number of road traffic accidents among young adult aged under 25 years old is an alarming issue in Malaysia. A five pages self-reported questionnaire was distributed to 384 young drivers' to investigate their intention in speeding while driving. Results have shown, the intention to speed among low and high intended based line group revealed a significant difference when it was compared with four types of scenario. Correct stimulation while driving could help drivers to change their intention to speed. This stimulation may be able to reduce the drivers' potential to involve with an accident and will save peoples' life.
\end{abstract}

Keywords: Speeding behavior; intention to speed; young driver's; urban university

2398-4295 @ 2017 The Authors. Published for AMER ABRA by e-International Publishing House, Ltd., UK. This is an open access article under the CC BY-NC-ND license (http://creativecommons.org/licenses/by-nc-nd/4.0/). Peer-review under responsibility of AMER (Association of Malaysian Environment-Behaviour Researchers), ABRA (Association of Behavioural Researchers on Asians) and cE-Bs (Centre for Environment-Behaviour Studies), Faculty of Architecture, Planning \& Surveying, UniversitiTeknologi MARA, Malaysia.

http://dx.doi.org/10.21834/ajbes.v2i7.41 


\section{Introduction}

Road traffic accident (RTA) frequently involves multi-level society, and this has become a demanding community issue where more serious participation is needed to improve driver's attitude in the future. RTA has a significant impact on quality of life and financial burden to the government and Malaysian society. The number of road traffic accidents among young adult is an alarming issue in Malaysia. Malaysian governments through relevant agencies have worked very hard to enforce all relevance acts related to it. One of the government prime objectives is to ensure safer Malaysian drivers in the future. To date, there were still a limited number of local research and evidence supporting the elements of driver's attitudes and behavior analysis had been conducted.

Driving is one of the most critical activities of daily living that involves the active eye, hand and foot coordination. Drivers that is not proficient or fail to organize and interact with their vehicle and surrounding environment may lead to road traffic injury (RTI) (Masuri, Md Isa, \& Mohd Tahir, 2012). This interaction could play a major role in preventing and predicting future studies.

The majority of road traffic accidents were caused by human error. This made the drivers' error as an important human component that needs to be further investigated. These road injuries and fatalities have become a great concern for the Malaysian government. This scenario may due to rapid development in Malaysia (Mohamad Ghazali Masuri, Akehsan Dahlan, Ajau Danis, \& Khairil Anuar Md Isa, 2015). This rapid development contributed to the increasing number of vehicle on the road that could potentially increase the possibilities of RTA. There were many causes of an accident either it is due to primary or secondary factors. Factors such as speeding, using a mobile phone and not wearing seat belt are considered as a contributing factor for injury and fatality(Mohamad Ghazali Masuri, Akehsan Dahlan, Ajau Danis, \& Khairil Anuar Md Isa, 2015; Md Isa et al., 2012). These numbers of fatality cases keep arising every year and had become a frightening issue in health and may contribute to significant effect on people quality of life indirectly (Wan Ahmad Kamal, Masuri, Dahlan, \& Md Isa, 2015). Many studies have proven that attitudes rarely present the synchronize behavior. Attitudes can be presented either in a positive or negative form. Even though attitude and behavior were not usually straightforward, and they are sensitive according to the social situation, but, attitude assessment can be used to predict future behaviour (Iversen, 2004). Understanding of human attitudes relates to driving behaviors were very critical to developing more appropriate planning and intervention in reducing the prevalence of RTA. At present, there was limited evidence available to justify which human components were needed to be addressed. Previous study shows that, different factors such as socio-demographic issues (Al-Naggar, Bobryshev, \& Mohd Noor, 2013), socioeconomic status (Masuri, Md Isa, \& Mohd Tahir, 2012), age/gender (Scott-Parker, Watson, King, \& Hyde, 2012), education level (Masuri, Md Isa, Mohd Tahir, et al., 2012) and living status (Al-Naggar et al., 2013) brought significant effects on driving behaviour. 


\section{Literature Review}

According to Scott-Parker, Hyde, Watson, and King (2012), individual aged 25 years old and below were considered as young drivers that frequently novices that are new to the driving experiences. A previous study had reported the percentage of young adult driver age between 17 and 24 commit traffic violations. The age group of the driver that strongly support the traffic violation countermeasure and moderate view toward traffic rule compliance was an older driver that aged 65+ (Vardaki \& Yannis, 2013). Speed over the limit was found to be one of the major causes of this accident. With regards to speeding behavior, there were many human components that usually become significant variables that need to be investigated. It created a lot of debates among society. However, there has been limited to work on this issue in Malaysia. The objective of this study is to identify which socio-demographics those have a high intention to speed and to compare the intention to speed in varieties of scenario (Scenario A - D). Each of the scenarios contains a different stimulus such as; driving with a best friend that they know as well as strangers.

Socio-demographic of human factor such as gender and age group were found to be very critical issues in determining the potential of involvement in RTA. The previous study indicates male had more intention involved in road violation (Speeding, mobile phoned used) compare to female (Horvath, Lewis, \& Watson, 2012b; Vardaki \& Yannis, 2013). Study done by (Özkan \& Lajunen, 2006) resulted driver score high on safety skill identified to be had better safety records compare to those that score high in perceptual-motor skill (which male reported to had higher score). In further explanation, they specify male driver generated a high score on dialling, answering, and a short message is sending compare to the other sex.

In committing road violation, a previous study showed strong evidence that one of the factors contributing off the violence action were influences from the passenger. Commonly the passengers were someone that familiar or well known by the driver such as friends, family members, and partner or work colleagues. From their perception, this group of the passenger would approve of their violence action on the road (Horvath, Lewis, \& Watson, 2012a; White, Hyde, Walsh, \& Watson, 2010).

Icek Ajren had developed the theory of planned behavior (TPB). According to this theory, the intention (which personal decisions) was according to attitude toward the act, subjective norm and perceived behavioral control (Ajzen, 1991). According to Forward, (2009) attitude are relying on the mixture of the beliefs about the behavior and evaluation of its effects. Furthermore, this author explained that normative belief and the motivation to create the subjective norm and the perceived behavioral controls were about the belief that encourages or to stop the behavior to be performed. Theory of planned behavior (TPB) had been used widely to explain a variety of the intentions and behavior of the road user. This included the study done by (Warner \& Åberg, 2006) which revealed that the component of the TPB can significantly explain up to $73 \%$ of the variance in intention to exceed the speed limits in urban and rural environments. The regression analysis models were done by Zhou, 
Wu, Patrick Rau, \& Zhang, (2009) found out that this theory framework also able to explained $43 \%$ to $48 \%$ variance in term of intention to use a hand-free and handheld mobile device.

\section{Methodology}

On July 2014, a cross-sectional study of convenience sample (undergraduate student) resides from Universiti Teknologi Mara, Kampus Puncak Alam was conducted. This study only included volunteered student who having provisional or open driving license and aged range in between 17-25 years old. The questionnaire used were adapted from Horvath et al., (2012a) which developed by using Theory of Planned Behavior. The questionnaire consists of two sections. Section 1 of the questionnaire consists of 10 demographic data that should be fulfilled by the respondent. The demographic data includes gender, age, faculty and course, level of education, driving licensed held (month), type of licensed, lifetime mileage, average minutes driving per week, frequency involves in traffic accident and the rate of participation in speeding behavior for the past three months. Section 2 of the questionnaire were includes four components that are intention, behavioral, normative and control beliefs. The first component was an intention that consists of four questions. The second component was behavioral beliefs that contain 14 questions. The last component was normative and control beliefs which each of them contains ten questions. The questionnaire also consists of five scenarios that name as Baseline scenario, scenario A, Scenario $B$, Scenario $C$ and Scenario $D$. Each of the scenarios contains a different stimulus such as; driving with a best friend that they know as well as strangers. Before research implementation, the ethical clearance was gathered from Faculty of Health Science and Committee Research Centre (CRC), Universiti Teknology Mara.

\section{Results and Discussions}

A total of $101(26.3 \%)$ male and $283(73.7 \%)$ female young novice driver from Universiti Teknologi Mara, Kampus Puncak Alam $(n=384)$ aged $17-25$ years $(M=21.18, S D=1.791)$ take part in this study. Most of the participation aged range from 22-24 years old and holding open licensed (held licensed more than two years). This study reveals no significant differences ( $p>0.05$ ) among male and female drivers about speed. This result contrast with the previous study that male had the higher intention to speed compare to female (Horvath et al., 2012a; Vardaki \& Yannis, 2013). The closer inspection revealed no significance association between socio-demographics with an intention to speed in all scenarios except one component. It was the rate of participation in speeding behavior for past three months in the baseline scenario that recorded significance association with intention to speed $(p<0.002)$. This finding consistent with previous research (Forward, 2009; Horvath et al., 2012a). The intention to speed among low and high intended based line group, shown a 
significant difference when it was compared with Scenario A, B, C and D $(p=<0.002)$. As an overall result, all respondent who falls under the category of high intended were recorded $18.617(p=0.000), 3.956(p=0.002), 5.875(p=0.000), 4.778(p=0.001)$ risk estimation when they drive under all scenarios.

Table 1 shows the details of participants demographic data (Gender, age, level of education, faculty and course attend, driving licensed held, type of licensed, lifetime mileage, average minutes spends driving per week, frequency involved in accident and type of vehicle most often drive). A total of 384 participants had responded their baseline was driving behavior assessment. From 384 respondents, 102 had successfully answer scenario $A$ followed by 94 in scenario $B, 96$ in scenario $C$ and 92 in scenario $D$. The current study result exposes that those that recognize the passenger well had the higher intention to speed. This is supported by the research interpreted by (Horvath et al., 2012b) which high level of identification of the passenger could lead to higher intention to speed.

Table 1: Demographic data

\begin{tabular}{|c|c|c|c|c|c|}
\hline Characteristic & $\begin{array}{l}\text { Baseline } \\
\text { scenario } \\
(\mathrm{N}=384)\end{array}$ & $\begin{array}{c}\text { Scenario } \\
A \\
(\mathrm{~N}=102)\end{array}$ & $\begin{array}{c}\text { Scenario } \\
B \\
(N=94)\end{array}$ & $\begin{array}{c}\text { Scenario } \\
\text { C } \\
(\mathrm{N}=96)\end{array}$ & $\begin{array}{c}\text { Scenario } \\
D \\
(N=92)\end{array}$ \\
\hline $\begin{array}{l}\text { Gender } \\
\text { Male } \\
\text { Female }\end{array}$ & $\begin{array}{l}101(26.3) \\
283(73.7)\end{array}$ & $\begin{array}{l}28(27.5) \\
74(72.5)\end{array}$ & $\begin{array}{l}26(27.1) \\
68(72.3)\end{array}$ & $\begin{array}{l}26(27.1) \\
70(72.9)\end{array}$ & $\begin{array}{l}21(22.8) \\
71(77.2)\end{array}$ \\
\hline $\begin{array}{c}\text { Age } \\
18-19 \\
20-21 \\
22-24\end{array}$ & $\begin{array}{c}120(31.3) \\
54(14.1) \\
210(54.7)\end{array}$ & $\begin{array}{l}32(31.4) \\
12(11.8) \\
58(56.9)\end{array}$ & $\begin{array}{c}25(26.6) \\
8(8.5) \\
61(64.9)\end{array}$ & $\begin{array}{l}37(38.5) \\
21(21.9) \\
38(39.6)\end{array}$ & $\begin{array}{l}26(28.3) \\
13(14.1) \\
53(57.6)\end{array}$ \\
\hline $\begin{array}{l}\text { Faculty and course } \\
\text { Foundation } \\
\text { Faculty of Health } \\
\text { Science } \\
\text { Others }\end{array}$ & $\begin{array}{l}117(30.5) \\
133(34.6) \\
134(34.9)\end{array}$ & $\begin{array}{l}31(30.4) \\
44(43.1) \\
27(26.5)\end{array}$ & $\begin{array}{l}24(25.5) \\
22(23.4) \\
48(51.1)\end{array}$ & $\begin{array}{l}37(38.5) \\
25(26.0) \\
34(35.4)\end{array}$ & $\begin{array}{l}25(27.2) \\
42(45.7) \\
25(27.5)\end{array}$ \\
\hline $\begin{array}{l}\text { Level of education } \\
\text { Foundation } \\
\text { Diploma } \\
\text { Degree }\end{array}$ & $\begin{array}{c}119(31.0) \\
10(2.6) \\
255(66.4)\end{array}$ & $\begin{array}{c}31(30.4) \\
6(5.9) \\
65(63.7)\end{array}$ & $\begin{aligned} 25 & (26.6) \\
1 & (1.1) \\
68 & (72.3)\end{aligned}$ & $\begin{array}{c}38(39.6) \\
2(2.1) \\
56(58.3)\end{array}$ & $\begin{aligned} 25 & (27.2) \\
1 & (1.1) \\
66 & (71.7)\end{aligned}$ \\
\hline $\begin{array}{c}\text { Driving licensed held } \\
\text { (months) } \\
1-24 \\
25-60 \\
61-96 \\
\end{array}$ & $\begin{array}{l}196(51.0) \\
144(37.5) \\
44(11.5)\end{array}$ & $\begin{array}{l}51(50.0) \\
36(35.3) \\
15(14.7)\end{array}$ & $\begin{array}{l}45(47.9) \\
38(40.4) \\
11(11.7)\end{array}$ & $\begin{array}{c}55(57.3) \\
34(35.4) \\
7(7.3)\end{array}$ & $\begin{array}{l}45(48.9) \\
36(39.1) \\
11(12.0)\end{array}$ \\
\hline $\begin{array}{l}\text { Type of licensed held } \\
\text { Provisional (P) } \\
\text { Open }\end{array}$ & $\begin{array}{l}170(44.3) \\
214(55.7)\end{array}$ & $\begin{array}{l}45(44.1) \\
57(55.9)\end{array}$ & $\begin{array}{l}33(35.1) \\
61(64.9)\end{array}$ & $\begin{array}{l}49(51.0) \\
47(49.0)\end{array}$ & $\begin{array}{l}43(46.7) \\
59(53.3)\end{array}$ \\
\hline $\begin{array}{c}\text { Lifetime mileage (km } \\
\text { per year) } \\
<10,000 \\
10,000-30,000 \\
>30,000\end{array}$ & $\begin{array}{l}242(63.0) \\
90(23.4) \\
52(13.5)\end{array}$ & $\begin{array}{l}63(61.8) \\
24(23.5) \\
15(14.7)\end{array}$ & $\begin{array}{l}54(57.4) \\
21(22.3) \\
19(20.2)\end{array}$ & $\begin{array}{c}65(67.7) \\
23(24.0) \\
8(8.3)\end{array}$ & $\begin{array}{l}60(65.2) \\
22(23.9) \\
10(10.9)\end{array}$ \\
\hline
\end{tabular}


Abang Mustaffa, D.N., et.al. / Asian Journal of Behavioural Studies, AjBeS, 2(7) Jul / Sep 2017 (p.43-51)

\begin{tabular}{|c|c|c|c|c|c|}
\hline $\begin{array}{c}\text { Average minutes } \\
\text { driving per week }\end{array}$ & $336(87.5)$ & $89(87.3)$ & $82(87.3)$ & $83(86.5)$ & $82(89.1)$ \\
$1-600$ & $25(6.5)$ & $8(7.8)$ & $7(7.4)$ & $7(7.3)$ & $3(3.3)$ \\
$\mathbf{6 0 1 - 1 2 0 0}$ & $12(3.1)$ & $2(2.0)$ & $5(5.3)$ & $3(3.1)$ & $2(2.2)$ \\
$1201-1800$ & $9(2.3)$ & $1(1.0)$ & $0(0.0)$ & $3(3.1)$ & $5(5.4)$ \\
$1801-2400$ & $2(0.5)$ & $2(2.0)$ & $0(0.0)$ & $0(0.0)$ & $0(0.0)$ \\
$2401-3000$ & & & & & \\
\hline $\begin{array}{c}\text { Frequency involve in } \\
\text { traffic accident }\end{array}$ & $280(72.9)$ & $75(73.5)$ & $64(68.1)$ & $72(75.0)$ & $69(75.0)$ \\
None & $101(26.3)$ & $26(25.5)$ & $30(31.9)$ & $22(22.9)$ & $23(25.0)$ \\
$1-5$ & $3(0.8)$ & $1(1.0)$ & $1.0(0.0)$ & $2(2.1)$ & $0(0.0)$ \\
6-10 & & & & & \\
Rate of participation & & & & & \\
in speeding & $186(48.4)$ & $44(47.9)$ & $45(47.9)$ & $51(53.1)$ & $46(50.0)$ \\
behaviour for past & $83(21.6)$ & $26(25.5)$ & $16(17.0)$ & $20(20.8)$ & $21(22.8)$ \\
three months & $36(9.4)$ & $10(9.8)$ & $10(10.6)$ & $12(12.5)$ & $4(4.3)$ \\
Not at all & $33(8.6)$ & $11(10.8)$ & $4(4.3)$ & $8(8.3)$ & $10(10.9)$ \\
Once or twice & $22(5.7)$ & $3(2.9)$ & $12(12.8)$ & $1(1.0)$ & $6(6.5)$ \\
Once or twice a week & $11(2.9)$ & $2(2.0)$ & $4(4.3)$ & $0(0.0)$ & $5(5.4) 0(0.0)$ \\
More than twice a & $13(3.4)$ & $6(5.9)$ & $3(3.2)$ & $4(4.2)$ & \\
week & & & & \\
Nearly once every & & & & & \\
day & & & & \\
Once daily & & & & \\
More than once a day & & & & \\
\hline
\end{tabular}

Table 2: The comparison of the intention to speed in varieties of scenario (Scenario A - D) with the baseline scenario.

\begin{tabular}{|c|c|c|c|c|c|c|c|c|}
\hline \multirow[t]{2}{*}{ Characteristic } & \multicolumn{4}{|c|}{$\begin{array}{c}\text { Scenario A } \\
(N=102)\end{array}$} & \multicolumn{4}{|c|}{$\begin{array}{c}\text { Scenario B } \\
(\mathrm{N}=94)\end{array}$} \\
\hline & $\begin{array}{c}\text { Low } \\
\text { intender }\end{array}$ & $\begin{array}{c}\text { High } \\
\text { intender }\end{array}$ & Sig. & $\begin{array}{l}\text { Risk } \\
\text { estimat } \\
\text { ion }\end{array}$ & $\begin{array}{c}\text { Low } \\
\text { intender }\end{array}$ & $\begin{array}{c}\text { High } \\
\text { intender }\end{array}$ & Sig. & $\begin{array}{c}\text { Risk } \\
\text { estimation }\end{array}$ \\
\hline \multirow{4}{*}{$\begin{array}{c}\text { Baseline } \\
\text { Scenario } \\
\text { Low intender } \\
\text { High intender }\end{array}$} & $\begin{array}{c}58 \\
(86.6) \\
9(13.4)\end{array}$ & $\begin{array}{c}9(25.7) \\
26(74.3)\end{array}$ & $\begin{array}{l}0.0 \\
00\end{array}$ & 18.617 & $\begin{array}{l}41(68.3) \\
19(31.7)\end{array}$ & $\begin{array}{l}12(35.3) \\
22(64.7)\end{array}$ & 0.002 & 3.956 \\
\hline & \multicolumn{4}{|c|}{$\begin{array}{c}\text { Scenario C } \\
(\mathrm{N}=96)\end{array}$} & \multicolumn{4}{|c|}{$\begin{array}{c}\text { Scenario D } \\
(\mathrm{N}=92)\end{array}$} \\
\hline & $\begin{array}{c}\text { Low } \\
\text { intender }\end{array}$ & $\begin{array}{c}\text { High } \\
\text { intender }\end{array}$ & Sig. & $\begin{array}{c}\text { Risk } \\
\text { estimat } \\
\text { ion }\end{array}$ & $\begin{array}{l}\text { Low } \\
\text { intender }\end{array}$ & $\begin{array}{c}\text { High } \\
\text { intender }\end{array}$ & Sig. & $\begin{array}{c}\text { Risk } \\
\text { estimation }\end{array}$ \\
\hline & $\begin{array}{c}47 \\
(81.0) \\
11 \\
(19.0)\end{array}$ & $\begin{array}{l}16(42.1) \\
22(57.9)\end{array}$ & $\begin{array}{l}0.0 \\
00\end{array}$ & 5.875 & $\begin{array}{l}43(68.3) \\
20(31.7)\end{array}$ & $\begin{array}{c}9(31.0) \\
20(69.0)\end{array}$ & 0.001 & 4.778 \\
\hline
\end{tabular}




\section{Conclusion}

Speeding behavior among young adult in Malaysia frequently involves must stimulation from our society. This behavior has become a demanding community issue where more serious community participation is needed to improve the future of young drivers. It is important to understand that, the stimulation that involves which contributed to risk-taking behavior among young drivers is usually beyond our control. It was a little unfair to solely depend only on the government to improve the drivers' behavior and their quality of life. Public participation such as parents, teachers and the most important thing; participants circle of friends, is to a large extent were needed in shaping a better future in the road and transportation system in Malaysia. A deeper understanding of the young drivers' behavior is needed to enhance the plan for preventive measures. For example the study on the differences of the belief among the high and low intender to speed by Forward, (2009) and Horvath et al., (2012a). Similarly, a study finding on the belief influencing drivers' hands-free and hand-held mobile phone use (White et al., 2010; Zhou et al., 2009). Such study finding can guide more relevant road safety solutions to encourage the safer road user behavior especially among the young adult nowadays. In future, to understand this situation, we must gain a deeper understanding of the beliefs underlying behind the driver's intention to speed for both genders. The finding of this study also suggested the intention to speed was caused by the pressure from the peer (or familiar person). By promoting safe behavior on the road for changing the views of the driver, it was predicted to have the capability to prevent RTA. Also, the result of this study could provide a good insight into the government, related agencies, and mass media to promote better road safety in future. Moreover, the other implication of this research was it can help Government to plan a more cost-effective campaign. The slogan such 'first class facility, this class mentality' should be changed to suit the status of developing the country by the year 2020. This evaluation could be used in screening and re-evaluation process of licensing in Malaysia. This evaluation also will be able to help the government in producing a better road society in the future. In summary, the current study concluded that correct stimulation while driving could help drivers to change their intention to speed. This behavior changes is important where it will be able to reduce the potential for accident and has an indirect effect on saves people life and increase the quality of life.

\section{Acknowledgement}

The highest appreciation goes to Scoot-Parker, Hyde, Watson \& King team by giving the guideline and allowing us to reproduced the questionnaire. This study would like to thank Ministry of Education Malaysia, Research Management Centre (RMC) Universiti Teknologi MARA (UiTM), CoRe Management Science, OPERA RIG, and all staff of the Faculty of Health Sciences UiTM Puncak Alam for continuous support in staff research and development. This study was funded by (600-RMI/FRGS 5/3 (118/2013). Lastly, specially 
mentioned to our beloved friend and research team; Allahyarham Anniz Fazli Ibrahim Bajunid.

\section{References}

Ajzen, I. (1991). The theory of planned behavior. Organizational behavior and human decision processes, 50(2), 179-211.

Al-Naggar, R. A., Bobryshev, Y. V., \& Mohd Noor, N. A. B. (2013). Lifestyle practice among Malaysian university students. Asian Pacific journal of cancer prevention, 14(3), 1895-1903. Retrieved from http://www.ncbi.nlm.nih.gov/pubmed/23679290

Forward, S. E. (2009). The theory of planned behaviour: The role of descriptive norms and past behaviour in the prediction of drivers' intentions to violate. Transportation Research Part F: Traffic Psychology and Behaviour, 12(3), 198-207. doi:http://dx.doi.org/10.1016/i.trf.2008.12.002

Horvath, C., Lewis, I., \& Watson, B. (2012a). The beliefs which motivate young male and female drivers to speed: A comparison of low and high intenders. Accident Analysis \& Prevention, 45(0), 334-341. doi:http://dx.doi.org/10.1016/j.aap.2011.07.023

Horvath, C., Lewis, I., \& Watson, B. (2012b). Peer passenger identity and passenger pressure on young drivers' speeding intentions. Transportation Research Part F: Traffic Psychology and Behaviour, 15(1), 52-64. doi:http://dx.doi.org/10.1016/j.trf.2011.11.008

Iversen, H. (2004). Risk-taking attitudes and risky driving behaviour. Transportation Research Part F: Traffic Psychology and Behaviour, 7(3), 135-150. doi:http://dx.doi.org/10.1016/j.trf.2003.11.003

Masuri, M. G., Dahlan, A., Danis, A., \& Md Isa, K. A. (2015). Public Participation in Shaping Better Road Users in Malaysia. Procedia - Social and Behavioral Sciences, 168(0), 341-348.

Masuri, M. G., Dahlan, A., Danis, A., \& Md Isa, K. A. (2015). Regeneration of Road System in the Urban Environment: Will Rehabilitation Components Orientate Road Users? Procedia - Social and Behavioral Sciences, 170(0), 700-708. doi:http://dx.doi.org/10.1016/j.sbspro.2015.01.072

Masuri, M. G., Md Isa, K. A., \& Mohd Tahir, M. P. (2012). Children, Youth and Road Environment: Road Traffic Accident. Procedia - Social and Behavioral Sciences, 38(0), 213-218.

Masuri, M. G., Md Isa, K. A., Mohd Tahir, M. P., Hassan, H. F., Hassan, Z., Jamhuri, F. Z., . . Noor, S. H. (2012). Behaviour Response among Health Sciences Students towards H1N1 Pandemic. Procedia - Social and Behavioral Sciences, 36(0), 77-86. doi:10.1016/j.sbspro.2012.03.009

Md Isa, K. A., Masuri, M. G., Abd Aziz, N. A., Md Isa, N. N., Hazali, N., Mohd Tahir, M. P., . . Hassan, H. F. (2012). Mobile Phone Usage Behaviour while Driving among Educated Young Adults in the Urban University. Procedia - Social and Behavioral Sciences, 36(0), 414-420. Retrieved from http://www.sciencedirect.com/science/article/pii/S1877042812005125 
Özkan, T., \& Lajunen, T. (2006). What causes the differences in driving between young men and women? The effects of gender roles and sex on young drivers' driving behaviour and self-assessment of skills. Transportation Research Part F: Traffic Psychology and Behaviour, 9(4), 269-277. doi:http://dx.doi.org/10.1016/j.trf.2006.01.005

Scott-Parker, B., Watson, B., King, M. J., \& Hyde, M. K. (2012). Confirmatory factor analysis of the Behaviour of Young Novice Drivers Scale (BYNDS). Accident Analysis \& Prevention, 49(0), 385-391. doi:http://dx.doi.org/10.1016/i.aap.2012.02.021

Vardaki, S., \& Yannis, G. (2013). Investigating the self-reported behavior of drivers and their attitudes to traffic violations. Journal of Safety Research, 46(0), 1-11. doi:http://dx.doi.org/10.1016/j.jsr.2013.03.001

Wan Ahmad Kamal, W. N. H., Masuri, M. G., Dahlan, A., \& Md Isa, K. A. (2015). Seat Belt Compliance and Quality of Life among Educated Young Adults in an Urban University. Procedia - Social and Behavioral Sciences, 202, 442-447. doi:http://dx.doi.org/10.1016/.j.sbspro.2015.08.249

Warner, H. W., \& Åberg, L. (2006). Drivers' decision to speed: A study inspired by the theory of planned behavior. Transportation Research Part F: Traffic Psychology and Behaviour, 9(6), 427-433. doi:http://dx.doi.org/10.1016/j.trf.2006.03.004

White, K. M., Hyde, M. K., Walsh, S. P., \& Watson, B. (2010). Mobile phone use while driving: An investigation of the beliefs influencing drivers' hands-free and hand-held mobile phone use. Transportation Research Part F: Traffic Psychology and Behaviour, 13(1), 9-20. doi:http://dx.doi.org/10.1016/j.trf.2009.09.004

Zhou, R., Wu, C., Patrick Rau, P.-L., \& Zhang, W. (2009). Young driving learners' intention to use a handheld or hands-free mobile phone when driving. Transportation Research Part F: Traffic Psychology and Behaviour, 12(3), 208-217. doi:http://dx.doi.org/10.1016/j.trf.2008.11.003 